\title{
PEMBERDAYAAN PENYANDANG DISABILITAS OLEH DINAS SOSIAL KOTA KEDIRI
}

\author{
*Krisnada ${ }^{1)}$, Sugeng Widodo ${ }^{2}$. \\ 1)Prodi Administrasi Publik, Fakultas Sosial dan Politik, Universitas Kadiri, Indonesia \\ 2) Prodi Administrasi Publik, Fakultas Sosial dan Politik, Universitas Kadiri, Indonesia \\ *Email Korespondensi: sugengwidodo@unik-kediri.ac.id
}

\begin{abstract}
Abstrak
Para penyandang disabilitas memiliki kelemahan secara fisik dan mental yang memiliki perbedaan bila dibandingkan dengan orang-orang normal, oleh sebab itu perlu adanya perhatian khusus dari pemerintah untuk memberdayakan ataupun kegiatan yang bersifat positif yang berguna untuk mengasah kemampuan para penyandang stabilitas. Maka dari itu peran pemerintah sangatlah perlu dalam pembinaan penyandang disabilitas. Lewat Dinas Sosial pemberdayaan penyandang disabilitas lebih terarah dan fokus. Tujuan penelitian ini untuk mendekripsikan upaya apa yang dilakukan serta kendala apa yang dihadapi dalam pemberdayaan penyandang disabilitas. Jenis metode yang digunakan dalam penelitian ini adalah metode deskriptif dengan pendekatan kualitatif. Teknik pengumpulan data yang digunakan yaitu, observasi, wawancara, dokumentasi. Hasil dari penelitian ini adalah upaya yang dilakukan Dinas Sosial adalah bantuan sosial untuk disabilitas berat berupa uang, dan juga pelatihan namun terhenti pertahun 2018 karena difokuskan di Dipnaker. Selain itu terdapat bantuan dari kemensos berupa bantuan sosial non tunai untuk semua klasifikasi penyandang disabilitas. Terdapat juga kegiatan penunjang lain dan juga UPSK dari Dinas Sosial Provinsi Jawa Timur.
\end{abstract}

Kata Kunci: pemberdayaan; penyandang disabilitas; peran pemerintah

\begin{abstract}
People with disabilities have physical and mental disabilities that have differences when compared to normal people, therefore there needs to be special attention from the government to empower or positive activities that are useful to hone the skills of the people with stability. Therefore, the role of the government is necessary for the development of people with disabilities. Through social services empowerment of people with disabilities is more targeted and focused. The purpose of this research is to decrypt what efforts are made as well as what obstacles are faced in the empowerment of people with disabilities. The type of method used in this study is a descriptive method with a qualitative approach. Data collection techniques used are, observation, interview, documentation. The result of this research is that the efforts made by Social Services are social assistance for severe disabilities in the form of money, as well as training but stalled per the year 2018 because it is focused in Dipnaker. Besides, there is assistance from the ministry in the form of non-cash social assistance for all classifications of people with disabilities. There are also other supporting activities as well as UPSK from the Social Service of East Java Province.
\end{abstract}

Keywords: empowerment; disability; government role 


\section{PENDAHULUAN}

Indonesia merupakan negara berkembang yang berusaha untuk melaksanakan pembangunan di segala aspek, baik itu secara fisik yang berupa infrastruktur maupun non fisik yaitu mental dan sumber daya manusianya. Berpenduduk terbesar ke-4 di dunia setelah Amerika Serikat dan dengan jumlah penduduk \pm 267 juta jiwa (Wuryandani, 2014). Dari jumlah tersebut penduduk yang memiliki keterbatasan fisik dan mental atau istilahnya adalah disabilitas hampir mendekati angka 9\% dari jumlah penduduk Indonesia atau sekitar 22 juta jiwa (Herdianti, 2019).

Dalam Jurnal Nasional SOCIA dijelaskan bahwa: Istilah difabel berasal dari bahasa Inggris dengan asal kata different ability, yang bermakna manusia yang memiliki kemampuan yang berbeda. Istilah tersebut digunakan sebagai pengganti istilah penyandang cacat yang mempunyai nilai rasa negative dan terkesan diskriminatif. Istilah difabel didasarkan pada realita bahwa setiap manusia diciptakan berbeda. Sehingga yang ada sebenarnya hanyalah sebuah perbedaan bukan kecacatan ataupun ke'abnormal'an (Sugi Rahayu et al., 2013).

Penyandang disabilitas di Indonesia masih dipandang sebelah mata, dianggap remeh karena tidak memiliki kesempurnaan secara fisik untuk melakukan suatu pekerjaan atau aktivitas tertentu. Rata-rata penyandang disabilitas memiliki background keluarga yang kurang mampu dan terbelakang. Dari segi kesejahteraan penyandang disabilitas sangat jauh sekali dari perhatian pemerintah dilihat sekarang mulai banyaknya peraturan perundang-undangan ataupun kebijakan yang mengatur tentang hak penyandang disabilitas dari usia balita sampai manula. Berdasarkan UU No 08 Tahun 2016 bagian ke13 tentang Hak Kesejahteraan Sosial berisi: Hak kesejahteraan sosial untuk Penyandang Disabilitas meliputi hak rehabilitasi sosial, jaminan sosial, pemberdayaan sosial, dan perlindungan sosial. Berdasarkan undang-undang tersebut dapat dijelaskan bahwa penyandang distabilitas dilindungi oleh negara dan tetap diberikan hak untuk hidup dengan sejahtera tanpa harus adanya diskriminasi antar sesama masyarakat.

Disamping itu, penyandang disabilitas juga berhak mendapatkan pelayanan yang sama dengan orang lain dalam bidang kesehatan, administrasi kependudukan bahkan sampai pelayanan pada saat pemilu. Hak-hak penyandang disabilitas ditegaskan dalam 
Pasal 42 Undang-Undang Dasar No. 39 Tahun 1999 tentang Hak Asasi Manusia yang berbunyi: Setiap warga Negara yang berusia lanjut, cacat fisik dan/atau cacat mental berhak memperoleh perawatan, pendidikan, pelatihan, bantuan khusus atas biaya negara, untuk menjamin kehidupan yang layak sesuai dengan martabat kemanusiaannya, meningkatkan rasa percaya diri dan kemampuan berpartisipasi dalam kehidupan bermasyarakat, berbangsa dan bernegara.

Para penyandang disabilitas memiliki kelemahan secara fisik dan mental yang memiliki perbedaan bila dibandingkan dengan orang-orang normal, sehingga haruslah mendapatkan suatu pemberdayaan ataupun kegiatan yang bersifat positif untuk menambah pendapatan ataupun mengasah kemampuan. Tuntutan dari berbagai aspek kehidupan menjadi dasar bagi penyandang disabilitas untuk menjadi masyarakat yang produktif. Mereka harus terus berupaya melakukan berbagai kegiatan yang mampu menghasilkan nilai tambah bagi dirinya dan mampu memberikan kontribusi kepada masyarakat dan pemerintah.

Permasalahan penyandang disabilitas muncul karena adanya suatu gangguan fisik sehingga menghambat mereka untuk melakukan aktivitas-aktivitas baik dari bidang ekonomi, politik maupun dalam kehidupan sosial seperti orang pada umumnya. Berdasarkan hasil pendataan tahun 2016 jumlah penyandang disabilitas dewasa yang tidak memiliki ketrampilan dan pekerjaan mencapai 67,33\% di 9 provinsi di Indonesia (Aminatun \& Hidayatullah, 2018). Dari jumlah tersebut dapat disimpulkan bahwa penyandang disabilitas masih belum produktif ataupun masih belum mendapat pembedayaan penuh dari pemerintah ataupun dukungan moril dari lingkungan sekitar. Padahal setiap warga negara berhak untuk mendapatkan pekerjaan dan penghidupan yang layak.

Maka dari itu peran pemerintah sangatlah perlu dalam pembinaan penyandang disabilitas. Lewat Dinas Sosial pemberdayaan penyandang disabilitas lebih terarah dan fokus. Salah satu upaya pemberdayaan penyandang disabilitas oleh Dinas Sosial yaitu:

1. Pemberdayaan bagi penyandang disabilitas merupakan suatu upaya untuk membantu meringankan beban dalam mencapai kesejahteraannya, dengan mendayagunakan agar dapat mengembangkan kemampuan yang dimiliki melalui 
pembinaan dan pelatihan yang intensif, sehingga mereka nantinya mempunyai bekal untuk dapat hidup secara mandiri tanpa bergantung pada orang lain.

2. Bakti sosial yaitu pemberian bahan sembako seperti beras, minyak, gula, telur, mie dll. Pemberian ini digunakan untuk keperluan sehari-hari

3. Biaya hidup untuk penyandang disabilitas berat. Disabilitas berat disini adalah seorang yang lumpuh total sejak lahir dan tidak bisa beraktivitas maksimal seperti orang pada umumnya. Biaya ini berasal dari APBD Kota Kediri. Biaya hidup disini meliputi biaya makan sehari-hari, peralatan seperti: kursi roda, tongkat tunanetra.

Di Kota Kediri penyandang disabilitas \pm 831 orang. Rinciannya, penyandang tuna daksa sebanyak 231 orang, tuna netra 85 orang, tuna rungu dan tuna wicara 170 orang, tuna grahita 164 orang, serta yang lainnya sebanyak 181 orang (Seles, 2018). Adapun Pemerintah Kota Kediri dibantu oleh Dinas Sosial mempunyai upaya rehabilitasi sosial disabilitas yang salah satu isinya yaitu tentang bagaimana pemberdayaan penyandang disabilitas. Oleh sebab itu peneliti tertarik untuk mengetahui bagaimana upaya yang dilakukan Dinas Sosial Kota Kediri Dalam Memperdayakan Penyandang Disabilitas.

\section{TINJAUAN PUSTAKA}

Berdasarkan penelitian yang dilakukan oleh (Hasan, 2018), menunjukkan hasil pemberdayaan distabilitas yang dilakukan oleh DPC PPDI kota Semarang menggunakan 5 strategi yang mampu dilakukan secara efisien serta. Adapun beberapa faktor pendukung dan penghambat penyandang disabilitas yang perlu untuk diupayakan agar pemberdayaan yang dilkukan oleh DPC PPDI mampu berjalan dengan baik. Pada penelitian ini menggunakan metode kualitatif yang mampu menghasilkan data deskriptif. Teknik analisannya menggunakan reduksi, penyajian data dan penyimpulan. Penelitian ini dilakukan karena adanya diskriminasi terhadap penyandang distabilitas, dimana kondisi tersebut mengakibatkan penyandang distabilitas tidak dapat berkembang dan merasa dikucilkan dari masyarakat, oleh sebab itu diharapkan dengan adanya penelitian mampu merubah pola piker atau sudut pandang terhadap penyandang distabilitas. 


\section{METODE PENELITIAN}

Berdasarkan pada permasalahan yang diteliti, jenis metode yang digunakan dalam penelitian ini adalah metode deskriptif dengan pendekatan kualitatif. Metode ini akan menggambarkan permasalahan atau kasus yang dikemukakan secara fakta yang ada dengan berpijak pada fakta yang bersifat khusus kemudian diteliti untuk dipecahkan permasalahannya dan ditarik kesimpulan secara umum. Menurut Bogdan dan Taylor, sebagaimana yang dikutip oleh Lexy J. Moleong, penelitian kualitatif adalah prosedur penelitian yang menghasilkan data deskriptif berupa kata-kata tertulis atau lisan dari orang-orang dan perilaku yang diamati (Moleong Lexy, 2000).

Sementara itu, penelitian deskriptif adalah suatu bentuk penelitian yang ditujukan untuk mendeskripsikan atau menggambarkan fenomena-fenomena yang ada, baik fenomena alamiah maupun rekayasa manusia (Nafis, 2013) Jadi metode penelitian kualitatif Menurut (Sugiono, 2016) adalah: metode penelitian yang berlandaskan pada filsafat postpositivisme, digunakan untuk meneliti pada kondisi obyek yang alamiah (lawannya adalah eksperimen) dimana peneliti sebagai instrumen kunci, teknik pengumpulan data dilakukan secara triangulasi (gabungan), analisis data bersifat induktif, dan hasil penelitian kualitatif lebih menekankan makna daripada generalisasi.

Sumber data dari penelitian ini adalah semua hal yang disampaikan dan tindakan dari para informan sebagai data primer dan tulisan atau dokumen-dokumen yang mendukung pernyataan informan. Penentuan informan dalam penelitian ini menggunakan teknik purposive sampling. Purposive sampling merupakan teknik pengambilan sampel sumber data dengan pertimbangan tertentu. Pertimbangan tertentu ini, misalnya orang tersebut yang dianggap paling tahu tentang apa yang kita harapkan, atau mungkin dia ebagai penguasa sehingga akan memudahkan peneliti menjelajahi obyek/situasi sosial yang diteliti (Sugiono, 2016). Informan yang menjadi sumber informasi pada peneliti ini adalah Kepala Seksi Pelayanan dan Rehabilitasi Sosial Disabilitas Kota Kediri, Staf Pelayanan dan Rehabilitasi Sosial Disabilitas Kota Kediri serta Komunitas-komunitas Penyandang Disabilitas yang berada di Kota Kediri. 


\section{HASIL DAN PEMBAHASAN}

Pemberdayaan yang dilakukan Dinas Sosial Kota Kediri sebagai lembaga resmi yang berwenang dibidang kesejahteraan sosial mengupayakan agar pemberdayaan yang didapat oleh para penyandang disabilitas ini merata se-Kota Kediri. Disamping dari lembaga resmi Dinas Sosial juga mengajak masyarakat turut aktif untuk ikut serta dalam pemberdayaan ini. Mereka yang berkebutuhan khusus ini perlu didorong agar mereka semangat, mereka mampu untuk memenuhi kebutuhan sendiri. Program-program yang dibuat Dinas Sosial juga mengupayakan agar para penyandang ini mendapatkan bantuan semua, mulai dari tunai maupun non-tunai seperti bahan sembako atau untuk membantu modal usahanya.

Bantuan sosial disabilitas berat sasarannya adalah para penyandang disabilitas yang lumpuh total, mereka tidak berdaya. Pemerintah kota dengan anggaran Rp. 6.000.000,00/tahun khusus bagi disabilitas berat adalah upaya yang dilakukan untuk memperdayakan para penyandang disabilitas. Karena penyandang disabilitas adalah orang dengan keterbatasan fisik sejak lahir maka, penderita disabilitas ini juga termasuk, penderita disini adalah orang yang semula mempunyai fisik lengkap akibat kecelakaan atau hal lain yang mengakibatkan orang tersebut mempunyai kecacatan secara fisik maupun mental. Banyak sekali kasus tersebut dan di Dinas Sosial ini mengupayakan rehabilitasi sosial bagi penyandang disabilitas. Karena Dinas Sosial Kota/Kabupaten tidak berwenang dalam proses rehabilitasinya melainkan UPT atau balai rehabilitasi sosial yang berada di provinsi dan kemesos, maka peran Dinas Sosial yang berada di provinsi dan Kemensos, maka peran Dinsos disini hanya sebagai assesment awal saja, mendata warga Kota Kediri yang memungkinkan untuk direhabilitasi terkait mental dan psiko sosialnya.

Bantuan sosial saja tidak cukup, tujuan dari pemberdayaan adalah meningkatkan kekurang beruntungan kepada keberdayaan, yang artinya adalah adanya suatu peningkatan mutu kehidupan dalam suatu individu atau masyarakat baik dalam hal ekonomi, sosial, hukum, politik atau dalam berbagai hal yang masih ada ketidakadilan di dalamnya begitu pula pemberdayaan oleh Dinas Sosial Kota Kediri yang memiliki berbagai tujuan mulia untuk meningkatkan kepercayaan diri para penyandang disabilitas dengan cara mengangkat harkat dan martabat para penyandang disabilitas dari segala 
ketidakadilan dan dari segala diskriminasi yang mereka alami. Menurut penuturan $\mathrm{Bu}$ Endang selaku Kepala Seksi Rehabilitasi Penyandang Disabilitas terdapat pelatihan bagi penyandang disabilitas setiap tahunnya. Mulai dari menjahit, komputer, membatik, tenun, wirausaha dsb. Namun sayang-nya pelatihan itu harus terhenti di tahun 2018 dikarenakan pelatihan sudah difokuskan di Dinas Tenaga Kerja. Padahal dari segi pemberdayaan pelatihan ini sangat membantu para penyandang disabilitas agar mempunyai ketrampilan, tidak diremehkan, tidak dikucilkan oleh warga sekitar. Penyandang disabilitas dengan segala permasalahan yang masih dialaminya sekarang terus berjuang untuk membuktikan kepada masyarakat yang mempunyai daya atau kekuatan bahwa penyandang disabilitas mampu mandiri dan mempunyai daya walaupun dengan keterbatasan fisik serta hak-hak yang belum mereka dapat yang menghambat proses mereka belajar dan untuk mengasah kemampuan.

Terkait dengan upaya yang dilakukan Pemkot ada program khusus dari kementrian sosial yaitu mengirim PPD Kemensos (Pendamping Penyandang Disabilitas Kementrian Sosial) tugasnya yaitu memberdayakan para penyandang disabilitas lewat bantuan sosial menyeluruh artinya semua klasifikasi disabilitas bisa mendapatkan bantuan. Dikarenakan jumlah penyandang disabilitas belum sepenuhnya mendapat bantuan daerah, maka pihak Kemensos mengirim perwakilannya ke daerah Kota/Kabupaten. Dengan persyaratan yang cukup mudah, petugas yang memadai, dengan dibantu oleh kelurahan dan pengambilannya bisa diwakilkan, proses tersebut berjalan dengan lancar.

Upaya lain yang dilakukan Dinas Sosial dalam bidang ketenagakerjaan adalah merekrut tenaga penyandang disabilitas. Namun karena terbentur peraturan Kemenpan-rb yang menyatakan bahwa perekrutan ASN (Aparatur Sipil Negara) melalui 2 jalur yaitu CPNS P3K. Pak Hillus memberikan pernyataan bahwa "karena tidak boleh merekrut tadi akhirnya kita pakai dasar hukumnya yaitu pengadaan barang dan jasa, jadi kita merekrut tenaga lewat kegiatan jadi statusnya bukan tenaga kontrak seperti p3k, disini ada 1 tuna netra 1 tuna daksa, di kominfo 1 orang tuna runguwicara, jadi sudah ada beberapa penyandang disabilitas yang masuk dibirokrasi, untuk sementara biar mereka mewarnai upaya kita, menjembatani informasi dengan disabilitas lain". 
Kegiatan-kegiatan yang dilakukan pun beragam, memperingati HDI (Hari Disabilitas Internasional) setiap tahunnya dengan berbagai tema acara yang beragam dan juga kegiatan tahunan dari Dinas Sosial Provinsi seperti UPSK (Unit Pelayanan Sosial Keliling). Disamping itu para penyandang ini mempunyai grub band bernama santaro band beranggotakan 5 orang dari penyandang disabilitas tuna netra. Mereka sudah aktif tampil di acara-acara dan sedang proses membuat lagu dengan promosinya di youtube.

Berdasarkan penjelasan diatas peneliti ingin mengaitkan dengan teori tentang strategi pemberdayaan masyarakat yang dikutip dari buku Edi Suharto (Suharto, 2005) antara lain:

\section{Motivasi}

Dalam hubungan ini setiap keluarga harus dapat memahami nilai kebersamaan, interaksi sosial dan kekuasaan melalui pemahaman akan haknya sebagai warga negara dan anggota masyarakat. Karena itu, setiap rumah tangga perlu didorong untuk membentuk kelompok yang merupakan mekanisme kelembagaan penting untuk mengorganisir dan melaksanakan kegiatan pengembangan masyarakat di desa atau kelurahannya. Kelompok ini kemudian dimotivasi untuk terlibat dalam kegiatan peningkatan pendapatan dengan menggunakan sumber-sumber dan kemampuankemampuan mereka sendiri.

\section{Peningkatan Kesadaran Dan Pelatihan Kemampuan}

Peningkatan kesadaran masyarakat dapat dicapai melalui pendidikan dasar, perbaikan kesehatan, imunisasi dan sanitasi. Sedangkan keterampilan-keterampilan vokasional bisa dikembangkan melalui cara-cara partisipatif. Pengetahuan lokal yang biasanya diperoleh melalui pengalaman dapat dikombinasikan dengan pengetahuan dari luar. Pelatihan semacam ini dapat membantu masyarakat untuk menciptakan mata pencaharian sendiri atau membantu meningkatkan keahlian mereka untuk mencari pekerjaan di luar wilayahnya.

\section{Manajemen Diri}

Setiap kelompok-kelompok harus mampu memilih pemimpin mereka sendiri dan mengatur kegiatan mereka sendiri, seperti melaksanakan pertemuan-pertemuan 
melakukan pencatatan dan pelaporan, mengoperasikan tabungan dan kredit, resolusi konflik dan manajemen kepemimpinan masyarakat. Pada tahap awal, pendampingan dari luar dapat membantu mereka dalam mengembangkan sebuah sistem. Kelompok kemudian dapat diberi wewenang penuh untuk melaksanakan dan mengatur sistem tersebut.

\section{Mobilisasi Sumber Daya}

Untuk memobilisasi sumber daya masyarakat, diperlukan pengembangan metode untuk menghimpun sumber-sumber individual melalui tabungan reguler dan sumbangan sukarela dengan tujuan meniciptakan modal social (Kusumastuti, 2015). Ide ini didasari pandangan bahwa setiap orang memiliki sumbernya sendiri yang jika dihimpun dapat meningkatkan kehidupan sosial ekonomi secara subtansial. Pengembangan sistem penghimpunan, pengalokasian dan penggunaan sumber perlu dilakukan secara cermat sehingga semua anggota memiliki kesempatan yang sama. Hal ini dapat menjamin kepemilikan dan pengelolaan secara berkelanjutan.

\section{Pembangunan dan pengembangan jejaring.}

Pengorganisasian kelompok-kelompok swadaya masyarakat perlu disertai dengan peningkatan kemampuan bagi para anggotanya membangun dan mempermudahkan jaringan dengan berbagai sistem sosial di sekitarnya (Nasmi \& Maani, 2019). Jaringan ini sangat penting dalam menyediakan dan mengembangan berbagai akses terhadap sumber dan kesempatan bagi peningkatan keberdayaan masyaraka. Setelah berbagai data tentang strategi pemberdayaan diatas dijelaskan, untuk mengaplikasikan pemberdayaan masyarakat dengan tujuan masyarakat yang mandiri dalam hal ini adalah masyarakat penyandang disabilitas tentunya dibutuhkan strategi pula, Dinas Sosial Kota Kediri pun mempunyai strategi khusus dalam pemberdayaannya, karena kerberhasilan suatu pemberdayaan juga karena adanya strategi itu pula. Dan strategi pemberdayaan penyandang disabilitas oleh Dinas Sosial Kota Kediri sudah sesuai dengan strategi yang dikemukakan oleh Edi Suharto sebagai berikut:

1) Motivasi

Penyandang disabilitas disini biasanya cukup tertutup dengan dunia luar, mereka seakan menutup diri tidak mau membaur dengan masyarakat karena keterbatasan fisiknya, 
juga dari pihak keluarga seakan menyembunyikan karena malu dari segi ekonomi mereka juga masih rendah karena rata-rata mereka tidak mempunyai pekerjaan. Dari sikap tersebut motivasi dari diri seorang penyandang disabilitas belum terbentuk, upaya yang dilakukan Dinas Sosial disini adalah advokasi, advokasi merupakan upaya-upaya dari atau atas nama, individu-individu maupun kelompok yang diperlakukan secara tidak adil, untuk mempengaruhi keputusan-keutusan dan perilaku masyarakat yang memiliki kekuasaan untuk menghentikan ketidakadilan tersebut. Banyak cara dalam mendefinisikan istilah advokasi. Advokasi dalam panduan ini secara luas mengacu pada hal-hal berikut ini:

A. Serangkaian tindakan yang diarahkan kepada perubahan kebijakan, sikap atau program dari berbagai jenis lembaga, pemerintah, maupun swasta.

B. Menempatkan suatu masalah ke dalam agenda, memberikan jalan keluar bagi masalah tersebut dan membangun dukungan tindakan untuk memecahkan masalah tersebut.

C. Bekerja bersama dengan orang dan organisasi lain untuk membuat perubahan Advokasi

Dinas Sosial berusaha semaksimal mungkin agar mereka penyandang disabilitas ini mendapatkan bantuan secara merata, baik itu bantuan secara tunai maupun non tunai. Dinas Sosial juga bekerjasama dengan kelurahan masing-masing untuk mendata warganya yang mempunyai keterbatasan secara fisik ataupun mental. Disamping program bantuan sosial juga terdapat program untuk penyandang disabilitas eks trauma yang semula mereka tidak memiliki kecacatan secara fisik ataupun mental karena kecelakaan atau sebab tertentu mereka memiliki kecacatan secara fisik ataupun mental, dengan cara direhabilitasi meskipun hanya mendata assesment awal saja karena pihak yang berhak melakukan rehabilitasi adalah UPT Provinsi.

2) Peningkatatan kesadaran dan pelatihan kemampuan

Penyandang disabilitas disini mengalami diskriminasi dalam masyarakat seperti masyarakat kelas sosial ekonomi rendah, kelompok minoritas etnis, wanita, populasi lanjut usia, karena ketidakberdayaannya. Keadaan dan perilaku mereka yang berbeda dari "keumuman" sering dipandang sebagai deviant (penyimpangan). Mereka seringkali 
kurang dihargai dan bahkan di cap sebagai orang yang malas, lemah, yang disebabkan oleh dirinya sendiri. Padahal ketidakberdayaan mereka seringkali merupakan akibat dari adanya ketidakadilan dan diskriminasi dalam aspek-aspek tertentu (Suharto, 2005). Dalam kenyataan tersebut masih banyak dijumpai ketidakdilan oleh karena itu kelompok disabilitas berhak atas hak-hak dan kewajiban yang seharusnya mereka dapat sebagai bagian dari warna Negara Republik Indonesia.

Dinas sebagai lembaga resmi yang menaungi tentang kesejahteraan sosial masyarakat melakukan salah satu cara untuk memberdayakan khususnya para penyandang disabilitas untuk melakukan pelatihan berupa menjahit untuk tuna rungu wicara, pijet untuk tuna netra, membatik, tenun dsb. Pelatihan ini secara tidak sengaja dapat membentuk bakat dari masing-masing individu, mulai terlihat minat apa yang digemari para penyandang disabilitas ini. Setelah pelatihan, mereka juga diberikan alatalat seperti mesin jahit, canting, lilin untuk dibawa pulang agar bakat mereka semakin terasah.

\section{3) Manajemen diri}

Dinas Sosial disini mendukung organisasi penyandang disabilitas seperti organisasi Gerkatin yang mempunyai usaha tata busana yang anggotanya berupa penyandang disabilitas tuna runguwicara. Selain itu juga organisasi Pertuni juga mempunyai sebuah grup band yang bernama Santaro Band yang anggotanya adalah penyandang disabilitas tuna netra dan 1 tuna grahita, grup band yang terbentuk tahun 2016 ini aktif manggung dan sedang proses membuat lagu sendiri. Dari 2 tadi pihak Dinsos juga akan mengupayakan organisasi-organisasi lain untuk turut serta dalam keterlibatan kemampuan mereka untuk keberlangsungan kehidupan mereka di masa mendatang. Mereka mempunyai kegiatan untuk meng-upgrade dirinya menjadi lebih berguna.

4) Mobilisasi sumber daya

Pemberdayaan penyandang disabilitas harus mempunyai sumber daya untuk menggerakkan kegiatan yang ada di dalamnya. Sumber daya yang dimaksudkan adalah anggaran dana untuk kegiatan. Pemerintah Kota Kediri lewat Dinas Sosial menganggarkan Rp. 6.000.000,00/ tahun dari APBD untuk membantu penyandang disabilitas berat di Kota Kediri. 


\section{5) Pembangunan dan pengembangan jejaring}

Para penyandang dan organisasi disabilitas disini membutuhkan akses untuk meningkatkan keberdayaan mereka. Contoh aksesnya adalah kegiatan workshop kewirausahaan yang mengundang para pengusaha kediri sebagai pembicara, pihak dinas sosial disini menjembatani antara para penyandang disabilitas yang ingin atau sudah mempunyai usaha dengan para pengusaha untuk bekerjasama atau memberi arahan bagi penyandang disabilitas.

Berdasarkan penjelasan diatas Dinas Sosial terus berupaya untuk memperdayakan para penyandang disabilitas serta memperjuangkan hak-hak penyandang disabilitas yang terabaikan. Dari ketidakberdayaan menuju keberdayaan adalah mimpi seluruh penyandang disabilitas yang berada di Kota Kediri. Dengan demikian Dinas Sosial memberikan pemberdayaan dengan pelatihan, bantuan sosial dan kegiatan tambahan yang mendukung. Lewat berbagai pemberdayaan tersebut diharapkan para penyandang disabilitas Kota Kediri lebih mampu memenuhi kebutuhannya.

\section{KESIMPULAN DAN SARAN}

Berdasarkan hasil penelitian dan analisa tentang Pemberdayaan Penyandang Disabilitas oleh Dinas Sosial Kota Kediri selanjutnya akan dikemukakan kesimpulan bahwa: upaya yang dilakukan Dinas Sosial dalam pemberdayaan penyandang disabilitas meliputi: Pembinaan Para penyandang Disabilitas dan Eks Trauma kegiatannya adalah pendayagunaan penyandang disabilitas dan eks trauma. Sub kegiatannya berupa bantuan sosial berupa uang tunai untuk disabilitas berat. Dengan bantuan sebesar Rp.500.000,00/bulan untuk 1 orang disabilitas berat. Dana tersebut berasal dari APBD Kota Kediri. Sedangkan untuk penyandang eks traumanya yaitu dengan cara direhabilitasi. Eks trauma disini terkait dengan mental, psikologis sosialnya. Tempat rehabilitasinya ada di UPT Rehabilitasi Sosial Provinsi, Dinas Sosial disini hanya pendataan awal. Selain bantuan sosial juga ada pelatihan seperti: menjahit, pijet, menyablon, membatik, tenun, dsb. Tahun 2018 adalah tahun terakhir pelatihan di Dinas Sosial karena sejak saat itu pelatihan lebih difokuskan di Dinas Tenaga Kerja. 
Program dari kemensos petugasnya adalah PPD (Pendamping Penyandang Disabilitas) Kemensos. Bantuannya berupa uang tunai senilai Rp. 300.000/bulan pada tahun 2019. Namun di tahun 2020 jumlahnya berkurang menjadi Rp 150.000/bulan. Kegiatan yang dilakukan yaitu: Gelar Cipta Produk dalam rangka HDI (Hari Disabilitas Internasional), Workshop, UPSK (Unit Pelayanan Sosial Keliling) dan Organisasi yang aktif untuk para penyandang disabilitas di Kota Kediri ada 4 yaitu: Gemanurani, Himpunan Wanita Disabilitas Indonesia (HWDI), Gerkatin dan Pertuni. Dan juga membentuk sebuah band yang bernama Santaro Band yang anggotanya adalah tuna netra dan tuna grahita.

Kendala-kendala yang dihadapi adalah dari penyandang disabilitas sendiri egonya masih tinggi, dan juga dari komunikasinya kurang lancar atau tidak nyambung dikarenakan keterbatasan fisik. Pada saat penciran bantuan non-tunai yaitu melalui atm, pengambilannya tidak bisa diwakilkan karena harus tanda tangan dengan penyandang disabilitas yang bersangkutan. Sedangkan saran dari peneliti adalah penelitian yang telah dilakukan maka dapat memberikan beberapa saran yang diharapkan dapat membangun maupun dapat dijadikan masukan serta pertimbangan oleh Dinas Sosial Kota Kediri dalam pemberdayaan penyandang disabilitas. Adapun saran-saran yang dapat diberikan oleh peneliti dalam penelitian ini, bahwa penyandang disabilitas banyak yang sudah terbantu dan merasakan dampak nyata dengan berbagai agenda program kegiatan, bantuan dan lain-lain. Kondisi tersebut harus dipertahankan atau ditingkatkan lagi agar kesetaraan dan keadilan penyandang disabilitas di Kota Kediri semakin terjamin. Perlu adanya kegiatan seperti pelatihan yang digalakkan khusus oleh Dinas Sosialnya sendiri, karena bantuan sosial saja dirasa belum cukup untuk memberdayakan para penyandang disabilitas.

\section{REFERENSI}

Aminatun, S., \& Hidayatullah, A. N. 2018. Pelayanan Sosial Yayasan Ciqal Terhadap Penyandang Disabilitas. Sosio Konsepsia, 6(3), 269-286.

Hasan, M. N. 2018. Pemberdayaan Penyandang Disabilitas Oleh DPC PPDI Kota Semarang. Skripsi.

Herdianti, S. 2019. Analisis Migrasi Risen berdasarkan Hasil Survei Penduduk Antar 
Sensus (SUPAS) tahun 2015 di Kabupaten Grobogan, Jawa Tengah. Universitas Muhammadiyah Surakarta.

Kusumastuti, A. 2015. Modal sosial dan mekanisme adaptasi masyarakat pedesaan dalam pengelolaan dan pembangunan infrastruktur. Masyarakat: Jurnal Sosiologi, 81-97.

Moleong Lexy, J. 2000. Metodelogi Penelitian Kualitatif. Remaja Posdakarya, Bandung.

Nafis, I. U. 2013. Pelaksanaan pembelajaran agama Islam bagi penyandang tuna netra di balai rehabilitasi sosial Distrarastra Pemalang II. IAIN Walisongo.

Nasmi, M. H., \& Maani, K. D. 2019. Pemberdayaan Masyarakat Miskin Melalui Kelompok Usaha Bersama (KUBE) Di Kecamatan Bintan Timur Oleh Dinas Sosial Kabupaten Bintan. Dialektika Publik: Jurnal Administrasi Negara Universitas Putera Batam, 3(2), 1-8.

Seles, M. 2018. Efektifitas Pasal 9 Peraturan Daerah Kota Kediri Nomor 4 Tahun 2013 Tentang Pembinaan Anak Jalanan, Gelandangan, Dan Pengemis (Studi Di Kantor Dinas Sosial Dan Tenaga Kerja Kota Kediri). Universitas Brawijaya.

Sugi Rahayu, Dewi, U., \& Ahdiyana, M. 2013. Pelayanan Publik Bidang Transportasi Bagi Difabel di Daerah Istimewa Yogyakarta. Universitas Negeri Yogyakarta, 10(2), 108-119.

Sugiono, S. 2016. Metode Penelitian Kuantitatif, Kualitatif, dan $R \& D$. Bandung: Alfabeta.

Suharto, E. 2005. Membangun Masyarakat Memberdayakan Rakyat Kajian Strategis Pembangunan Kesejahteraan Sosial dan Pekerjaan Sosial. PT Refika Aditama.

Wuryandani, D. 2014. Peluang dan tantangan SDM Indonesia menyongsong era masyarakat ekonomi asean. Info Singkat Ekonomi Dan Kebijakan Publik, 6(17), 1316.

Undang-Undang Dasar No. 39 Tahun 1999

Undang- Undang No 08 Tahun 2016 